\title{
Gardenoins E-H, Cycloartane Triterpenes from the Apical Buds of Gardenia obtusifolia
}

\author{
Thanesuan Nuanyar, ${ }^{a, b}$ Ruengrit SaPpapan, ${ }^{a}$ Tirayut VIlaivan, ${ }^{a}$ and Khanitha Pudhom ${ }^{*}, a$ \\ ${ }^{a}$ Research Centre of Bioorganic Chemistry, Department of Chemistry, Faculty of Science, Chulalongkorn University; and \\ ${ }^{b}$ Center for Petroleum, Petrochemicals, and Advanced Materials, Chulalongkorn University; Bangkok 10330, Thailand. \\ Received October 16, 2010; accepted December 20, 2010; published online December 24, 2010
}

Four new cycloartane triterpenes, named gardenoins $\mathrm{E}-\mathrm{H}(1-4)$, were isolated from the apical buds of Gardenia obtusifolia, together with five known cycloartanes. Only compound 1 displayed cytotoxicity against colon, hepatic and lung cancer cell lines.

Key words cycloartane; gardenoin; Gardenia obtusifolia; cytotoxicity

Plants belonging to the genus Gardenia have proved to produce a variety of cycloartane triterpenoids, some of which display interesting biological activities. ${ }^{1-5)}$ Additionally, extracts of various species exhibiting anti-implantation and abortifacient effects, ${ }^{6}$ and antiulcer, ${ }^{7}$ antibacterial, ${ }^{8)}$ diuretic, analgesic, hypertensive, and larvicidal activities ${ }^{9,10)}$ have been reported. Previous investigations on the plants in this genus have led to the isolation of an array of structurally diverse cycloartanes with a wide range of biological activities, particularly cytotoxic and anti-human immunodeficiency virus (HIV) effects. ${ }^{2,3)}$ Recently, we have also reported the isolation and identification of a number of cytotoxic 3,4seco-cycloartane triterpenoids from two species found in Thailand, G. sootepensis and G. tubifera. ${ }^{11,12)}$ This prompted us to investigate another plant in this genus, G. obtusifolia. The current paper describes the isolation, characterization and cytotoxicity of four new cycloartane triterpenes $(\mathbf{1}-\mathbf{4})$ from the EtOAc extract of apical buds of G. obtusifolia, together with five known compounds, dikamakiartanes $\mathrm{A}, \mathrm{C}$ and D (5-7), 5 $\alpha$-cycloart-24-ene-3,16,23-trione (8) and secaubryenol (9).

\section{Results and Discussion}

Gardenoin E (1) was obtained as a white, amorphous solid. Its molecular formula was established as $\mathrm{C}_{30} \mathrm{H}_{46} \mathrm{O}_{3}$ by the high resolution-electrospray ionization-mass spectrum (HR-ESI-MS) ion at $m / z \quad 477.3341 \quad[\mathrm{M}+\mathrm{Na}]^{+}$(Calcd 477.3345), indicating eight degrees of unsaturation. The IR absorption bands at 3439 and $1712 \mathrm{~cm}^{-1}$ implied the presence of hydroxyl and carbonyl functionalities. The ${ }^{1} \mathrm{H}-\mathrm{NMR}$ spectrum (Table 1) displayed a pair of doublets at $\delta_{\mathrm{H}} 0.58$ and $0.79(J=4.1 \mathrm{~Hz})$, characteristic of the C-19 methylene protons of cyclopropane ring of a cycloartane triterpene. ${ }^{13-16)}$ The ${ }^{13} \mathrm{C}-\mathrm{NMR}$ and heteronuclear single quantum coherence (HSQC) data revealed the presence of 30 nonequivalent carbons including two ketone carbonyls, six tertiary methyls, one secondary methyl, nine methylenes, six methines (one oxygenated and one olefinic) and six quaternary carbons (one olefinic). These NMR data indicated that three of the eight units of unsaturation come from one carbon-carbon double bond and two carbonyls. Therefore, the remaining five degrees required $\mathbf{1}$ to comprise a pentacyclic core. The above NMR data strongly suggested that $\mathbf{1}$ was a normal cycloartanone-type triterpenoid. The existence of two geminal vinylmethyls connected to a carbonyl group was corrobo- rated by heteronuclear multiple bond connectivity (HMBC) correlations from olefinic proton at $\delta_{\mathrm{H}} 6.11(\mathrm{H}-24)$ to a carbonyl $\left(\delta_{\mathrm{C}} 202.6, \mathrm{C}-23\right)$, Me-26 and Me-27. The NMR data of 1 were similar to those of $5 \alpha$-cycloart-24-ene-3,16,23-trione $(\mathbf{8}),{ }^{2)}$ except for the presence of a hydroxyl group at C-16 in-

Table 1. ${ }^{1} \mathrm{H}-\mathrm{NMR}$ Data $\left(400 \mathrm{MHz}, \mathrm{CDCl}_{3}\right)$ for Gardenoins $\mathrm{E}-\mathrm{H}(\mathbf{1}-\mathbf{4})$

\begin{tabular}{|c|c|c|c|c|}
\hline Position & $\mathbf{1}^{a)}$ & $2^{a)}$ & $3^{b)}$ & $4^{a)}$ \\
\hline \multirow[t]{2}{*}{1} & $1.22(\mathrm{~m})$ & $1.55(\mathrm{~m})$ & $1.30(\mathrm{~m})$ & $1.35(\mathrm{~m})$ \\
\hline & $1.87(\mathrm{~m})$ & $1.86(\mathrm{~m})$ & $2.11(\mathrm{~m})$ & $2.07(\mathrm{~m})$ \\
\hline \multirow[t]{2}{*}{2} & $2.31(\mathrm{~m})$ & $2.31(\mathrm{~m})$ & $2.32(\mathrm{~m})$ & $2.31(\mathrm{~m})$ \\
\hline & $2.70(\mathrm{~m})$ & $2.70(\mathrm{~m})$ & & $2.53(\mathrm{~m})$ \\
\hline \multicolumn{5}{|l|}{3} \\
\hline \multicolumn{5}{|l|}{4} \\
\hline 5 & $1.72(\mathrm{~m})$ & $1.74(\mathrm{~m})$ & $2.55(\mathrm{~m})$ & $2.42(\mathrm{~m})$ \\
\hline \multirow[t]{2}{*}{6} & $0.92(\mathrm{~m})$ & $0.99(\mathrm{~m})$ & 3.96 (brs) & $1.08(\mathrm{~m})$ \\
\hline & $1.57(\mathrm{~m})$ & $1.59(\mathrm{~m})$ & & $1.51(\mathrm{~m})$ \\
\hline \multirow[t]{2}{*}{7} & $1.18(\mathrm{~m})$ & $1.19(\mathrm{~m})$ & $1.31(\mathrm{~m})$ & $1.08(\mathrm{~m})$ \\
\hline & $1.36(\mathrm{~m})$ & $1.39(\mathrm{~m})$ & $1.97(\mathrm{~m})$ & $1.31(\mathrm{~m})$ \\
\hline 8 & $1.53(\mathrm{~m})$ & $1.50(\mathrm{~m})$ & $2.07(\mathrm{~m})$ & $1.57(\mathrm{~m})$ \\
\hline \multicolumn{5}{|l|}{9} \\
\hline \multicolumn{5}{|l|}{10} \\
\hline \multirow[t]{2}{*}{11} & $1.17(\mathrm{~m})$ & $1.19(\mathrm{~m})$ & $1.08(\mathrm{~m})$ & $1.31(\mathrm{~m})$ \\
\hline & $2.11(\mathrm{~m})$ & $2.12(\mathrm{~m})$ & $2.20(\mathrm{~m})$ & $2.06(\mathrm{~m})$ \\
\hline 12 & $1.72(\mathrm{~m})$ & $1.86(\mathrm{~m})$ & $1.59(\mathrm{~m})$ & $1.64(\mathrm{~m})$ \\
\hline \multicolumn{5}{|l|}{13} \\
\hline \multicolumn{5}{|l|}{14} \\
\hline \multirow[t]{2}{*}{15} & $1.43(\mathrm{~m})$ & $1.52(\mathrm{~m})$ & $1.25(\mathrm{~m})$ & $1.31(\mathrm{~m})$ \\
\hline & $1.88(\mathrm{~m})$ & $1.85(\mathrm{~m})$ & & \\
\hline \multirow[t]{2}{*}{16} & $4.00(\mathrm{~m})$ & $4.25(\mathrm{dd}, 5.7,8.2)$ & $1.17(\mathrm{~m})$ & $1.91(\mathrm{~m})$ \\
\hline & & & $1.89(\mathrm{~m})$ & \\
\hline 17 & $1.74(\mathrm{~m})$ & $2.07(\mathrm{~m})$ & $1.60(\mathrm{~m})$ & $1.59(\mathrm{~m})$ \\
\hline 18 & $1.05(\mathrm{~s})$ & $1.08(\mathrm{~s})$ & $0.97(\mathrm{~s})$ & $0.98(\mathrm{~s})$ \\
\hline \multirow[t]{2}{*}{19} & $0.58(\mathrm{~d}, 4.1)$ & $0.57(\mathrm{~d}, 4.0)$ & $0.42(\mathrm{~d}, 3.0)$ & $0.40(\mathrm{~d}, 4.3)$ \\
\hline & $0.79(\mathrm{~d}, 4.1)$ & $0.79(\mathrm{~d}, 4.0)$ & $1.11(\mathrm{~d}, 3.0)$ & $0.73(\mathrm{~d}, 4.3)$ \\
\hline 20 & $2.16(\mathrm{~m})$ & $2.10(\mathrm{~m})$ & $1.64(\mathrm{~m})$ & $1.46(\mathrm{~m})$ \\
\hline 21 & $0.97(\mathrm{~d}, 6.7)$ & $0.68(\mathrm{~d}, 5.8)$ & $0.75(\mathrm{~d}, 6.0)$ & $0.86(\mathrm{~d}, 6.4)$ \\
\hline \multirow[t]{2}{*}{22} & $2.41(\mathrm{dd}, 7.4,15.0)$ & $4.44(\mathrm{~d}, 4.2)$ & $2.16(\mathrm{~m})$ & $1.75(\mathrm{~m})$ \\
\hline & $2.83(\mathrm{dd}, 4.0,15.0)$ & & $2.60(\mathrm{~m})$ & $2.19(\mathrm{~m})$ \\
\hline 23 & & & & $5.60(\mathrm{brs})$ \\
\hline 24 & 6.11 (brs) & $6.16(\mathrm{~s})$ & $5.80(\mathrm{brs})$ & $5.60(\mathrm{brs})$ \\
\hline \multicolumn{5}{|l|}{25} \\
\hline 26 & $2.16(\mathrm{~s})$ & $2.23(\mathrm{~s})$ & $7.02(\mathrm{brs})$ & $1.31(\mathrm{brs})$ \\
\hline 27 & $1.90(\mathrm{~s})$ & $1.99(\mathrm{~s})$ & $1.83(\mathrm{~s})$ & 1.31 (brs) \\
\hline \multirow[t]{2}{*}{28} & $1.05(\mathrm{~s})$ & $1.04(\mathrm{~s})$ & $5.08(\mathrm{brs})$ & 4.73 (brs) \\
\hline & & & $5.14(\mathrm{brs})$ & 4.81 (brs) \\
\hline \multirow[t]{2}{*}{29} & $1.10(\mathrm{~s})$ & $1.09(\mathrm{~s})$ & $4.14(\mathrm{~d}, 13.0)$ & $1.69(\mathrm{~s})$ \\
\hline & & & $3.94(\mathrm{~d}, 13.0)$ & \\
\hline 30 & $1.15(\mathrm{~s})$ & $1.17(\mathrm{~s})$ & $0.91(\mathrm{~s})$ & $0.92(\mathrm{~s})$ \\
\hline
\end{tabular}

a) Recorded in $\mathrm{CDCl}_{3}$. b) Recorded in acetone- $d_{6}$. 
stead of a ketone carbonyl in $\mathbf{8}$. This was verified by HMBC correlations of $\mathrm{H}-16$ to $\mathrm{C}-14, \mathrm{C}-17$ and $\mathrm{C}-20$, and by ${ }^{1} \mathrm{H}-{ }^{1} \mathrm{H}$ correlation spectroscopy (COSY) correlations of $\mathrm{H}-16 / \mathrm{H}_{2}-15$ and H-16/H-17 (Fig. 1). Observed nuclear Overhauser effect spectroscopy (NOESY) correlations of Me-28/H-5, H-5/H$7 \alpha, \mathrm{H}-7 \alpha / \mathrm{Me}-30$ and $\mathrm{Me}-30 / \mathrm{H}-17$ indicated an $\alpha$-orientation of these protons, while the correlations of $\mathrm{H}-8 / \mathrm{Me}-18$ and $\mathrm{H}-$ $16 / \mathrm{Me}-18$ suggested that $\mathrm{H}-16$ is a $\beta$-orientation (Fig. 2). Additionally, the obvious NOESY correlation of $\mathrm{H}-17$ and Me21 together with chemical shift comparison of the side chain unit ( $\mathrm{C}-20$ to $\mathrm{C}-27$ ) with those of $\mathbf{8}$ determined the configuration of Me-21 to be in an $\alpha$-orientation. ${ }^{2)}$ The structure of 1 was thus assigned as shown.

Gardenoin F (2) was obtained as a white, amorphous solid, and its molecular formula $\mathrm{C}_{30} \mathrm{H}_{46} \mathrm{O}_{4}$ was deduced from the HR-ESI-MS ion at $m / z 493.3289 \quad[\mathrm{M}+\mathrm{Na}]^{+}$(Calcd 493.3294), 16 mass units more than 1. Comparison of the ${ }^{1} \mathrm{H}$ - and ${ }^{13} \mathrm{C}-\mathrm{NMR}$ spectra of $\mathbf{2}$ with those of $\mathbf{1}$ revealed them to be very similar, with the only difference being the appearance of a singlet due to an oxymethine proton at $\delta_{\mathrm{H}} 4.44$ in the ${ }^{1} \mathrm{H}-\mathrm{NMR}$ spectrum, coupled in the HSQC spectrum to a newly appearing an oxygenated methine carbon at $\delta_{\mathrm{C}} 78.7$, while a methylene signal at $\delta_{\mathrm{H}} 2.83(\mathrm{dd}, J=4.0,15.0 \mathrm{~Hz})$ and $2.41(\mathrm{dd}, J=7.0,15.0 \mathrm{~Hz})$, and at $\delta_{\mathrm{C}} 50.4$ had disappeared. The relative configuration of $\mathbf{2}$ was assigned to be the same
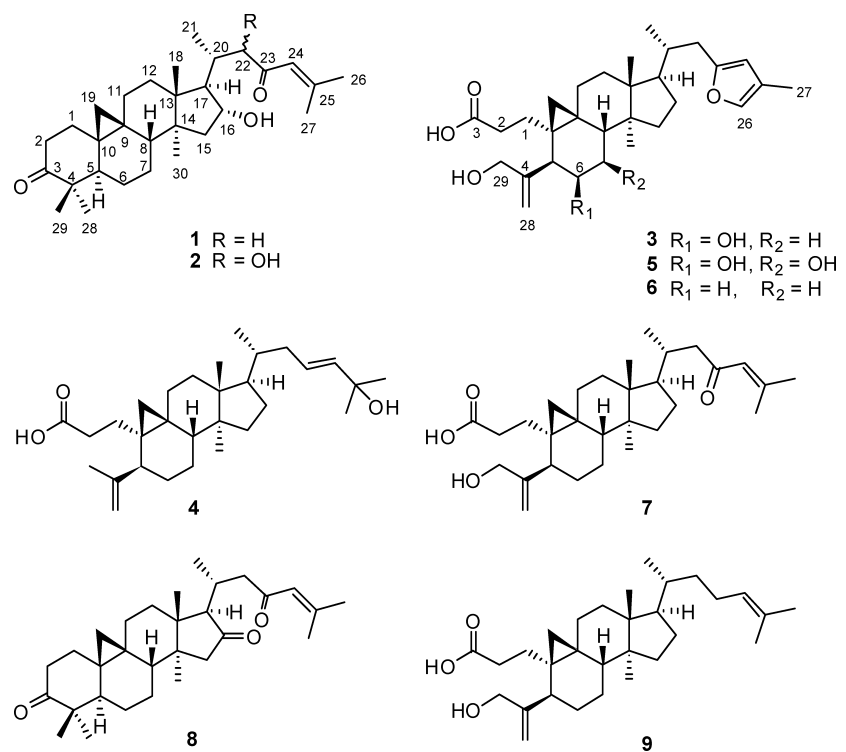

Chart 1. Structures of Isolated Compounds from Gardenia obtusifolia
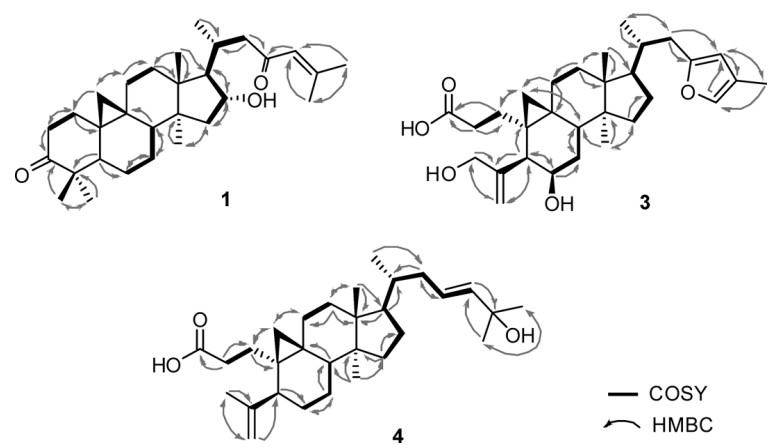

Fig. 1. Selected COSY and HMBC Correlations for Gardenoins E (1), G (3) and $\mathrm{H}(4)$ as that of $\mathbf{1}$ on the basis of the nuclear Overhauser effect (NOE) correlations.

Gardenoin G (3), a white, amorphous solid, had the molecular formula of $\mathrm{C}_{30} \mathrm{H}_{44} \mathrm{O}_{5}$ as established by HR-ESI-MS $(\mathrm{m} / \mathrm{z}$ 507.3087 $[\mathrm{M}+\mathrm{Na}]^{+}$, Calcd 507.3086). The ${ }^{1} \mathrm{H}-\mathrm{NMR}$ spectrum (Table 1) also displayed the characteristic signals for cyclopropane methylene protons of a cycloartane triterpene as two doublets at $\delta_{\mathrm{H}} 0.42$ and $1.11(J=3.0 \mathrm{~Hz})$, and two broad singlets of a terminal alkene at $\delta_{\mathrm{H}} 5.08$ and 5.14. These data suggested that $\mathbf{3}$ is a 3,4-seco-cycloartane triterpenoid. ${ }^{112)}$ Additionally, the NMR spectra indicated the presence of a 2,4-disubstituted furan ring $\left(\delta_{\mathrm{H}} 5.80\right.$ and 7.02; $\left.\delta_{\mathrm{C}} 108.4 \mathrm{CH}, 119.7 \mathrm{qC}, 136.9 \mathrm{CH}, 154.8 \mathrm{qC}\right)$ in side chain. Extensive analysis of 1D- and 2D-NMR spectra revealed that the structure of $\mathbf{3}$ was virtually identical to that of dikamaliartane A (5), ${ }^{17)}$ except for the presence of one more methylene group $\left(\delta_{\mathrm{H}} 1.31 \mathrm{~m}, 1.97 \mathrm{~m} ; \delta_{\mathrm{C}} 27.6\right)$ in place of the oxygenated methine at $\mathrm{C}-7$ position in $\mathbf{5}$. This was confirmed by HMBC correlations from $\mathrm{H}-6$ and $\mathrm{H}-8$ to $\mathrm{C}-7$ (Fig. 1). The relative stereochemistry of $\mathbf{3}$ was established to be the same as that of $\mathbf{5}$ on the basis of NOE correlations of $\mathrm{H}-5 / \mathrm{H}-$ 6, H-6/Me-30, H-17/Me-30 and H-8/Me-18. The configuration at C-20 was assumed to be the same as that of $\mathbf{5}$ and $\mathbf{6}$ because the carbon signals due to C-20-C-27 of $\mathbf{3}$ were superimposable with those previously reported. ${ }^{17)}$

Gardenoin H (4), a colorless gum, had the molecular formula of $\mathrm{C}_{30} \mathrm{H}_{48} \mathrm{O}_{3}$ as determined by HR-ESI-MS $(\mathrm{m} / \mathrm{z}$ 479.3496 $[\mathrm{M}+\mathrm{Na}]^{+}$, Calcd 479.3501). The ${ }^{1} \mathrm{H}-\mathrm{NMR}$ spectrum also showed typical signals associated with a 3,4-secocycloartane triterpene, including a characteristic pair of doublets at $\delta_{\mathrm{H}} 0.40$ and $0.73(\mathrm{~d}, J=4.3 \mathrm{~Hz})$, attributable to the C19 methylene protons in the cyclopropane ring, and two singlets of an exomethylene moiety at $\delta_{\mathrm{H}} 4.71$ and 4.73. A twoproton broad singlet at $\delta_{\mathrm{H}} 5.60$, showing HMBC correlations to $\mathrm{C}-24, \mathrm{C}-25$ and $\mathrm{C}-26$ (Fig. 1), was identified as a disubstituted alkene moiety between $\mathrm{C}-23$ and $\mathrm{C}-24$. The ${ }^{1} \mathrm{H}$ - and ${ }^{13} \mathrm{C}$-NMR of 4 were very similar to those previously reported of gardenoin $\left.\mathrm{D},{ }^{12}\right)$ with the marked difference being the appearance of an additional three-proton singlet of a vinylic methyl at $\delta_{\mathrm{H}} 1.69$ and $\delta_{\mathrm{C}} 19.7$, replacing the oxygenated methylene signals at C-29 in gardenoin D. The relative configuration of $\mathbf{4}$ was deduced to be the same as that of gardenoin D on the basis of the NOESY correlations.

The cytotoxicity of compounds $\mathbf{1}-\mathbf{8}$ was tested in vitro against five human tumor cell lines, BT474, CHAGO, HepG2, KATO-3 and SW-620 cell lines, in tissue culture. Only compound $\mathbf{1}$ showed to be cytotoxic against SW-620, KATO-

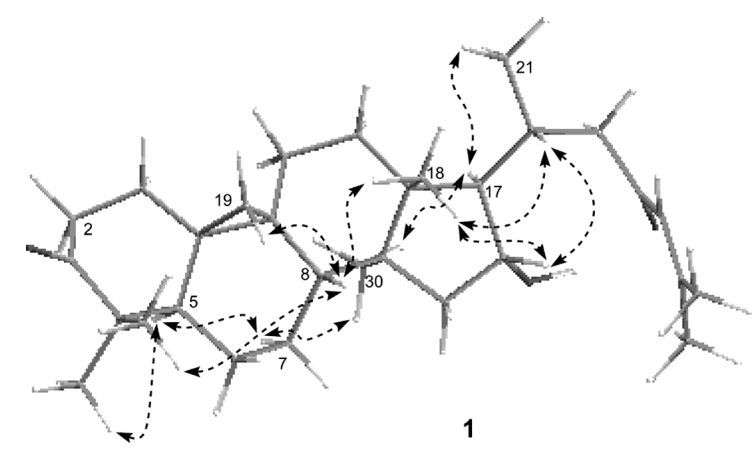

Fig. 2. Diagnostic NOE Correlations for $\mathbf{1}$ 
Table 2. ${ }^{13} \mathrm{C}-\mathrm{NMR}$ Data $\left(400 \mathrm{MHz}, \mathrm{CDCl}_{3}\right)$ for Gardenoins $\mathrm{E}-\mathrm{H}(\mathbf{1}-\mathbf{4})$

\begin{tabular}{|c|c|c|c|c|}
\hline Position & $\mathbf{1}^{a)}$ & $\mathbf{2}^{a)}$ & $3^{b)}$ & $4^{a)}$ \\
\hline 1 & $33.3, \mathrm{CH}_{2}$ & $33.3, \mathrm{CH}_{2}$ & $30.7, \mathrm{CH}_{2}$ & $28.8, \mathrm{CH}_{2}$ \\
\hline 2 & $37.4, \mathrm{CH}_{2}$ & $37.4, \mathrm{CH}_{2}$ & $31.3, \mathrm{CH}_{2}$ & $31.3, \mathrm{CH}_{2}$ \\
\hline 3 & $216.4, \mathrm{qC}$ & $216.5, \mathrm{qC}$ & 173.5, qC & 179.1, qC \\
\hline 4 & $50.2, \mathrm{qC}$ & $50.2, \mathrm{qC}$ & $149.7, \mathrm{qC}$ & $149.4, \mathrm{qC}$ \\
\hline 5 & $48.4, \mathrm{CH}$ & $48.4, \mathrm{CH}$ & $45.8, \mathrm{CH}$ & $45.9, \mathrm{CH}$ \\
\hline 6 & $21.4, \mathrm{CH}_{2}$ & $20.8, \mathrm{CH}_{2}$ & $67.4, \mathrm{CH}$ & $27.7, \mathrm{CH}_{2}$ \\
\hline 7 & $26.7, \mathrm{CH}_{2}$ & $26.7, \mathrm{CH}_{2}$ & 27.6, $\mathrm{CH}_{2}$ & $25.0, \mathrm{CH}_{2}$ \\
\hline 8 & $47.5, \mathrm{CH}$ & $48.1, \mathrm{CH}$ & $38.8, \mathrm{CH}$ & $47.7, \mathrm{CH}$ \\
\hline 9 & $20.4, \mathrm{qC}$ & $20.4, \mathrm{qC}$ & $20.7, \mathrm{qC}$ & $21.4, \mathrm{qC}$ \\
\hline 10 & $26.1, \mathrm{qC}$ & $26.1, \mathrm{qC}$ & $24.8, \mathrm{qC}$ & $27.0, \mathrm{qC}$ \\
\hline 11 & $26.0, \mathrm{CH}_{2}$ & $26.0, \mathrm{CH}_{2}$ & 25.9, $\mathrm{CH}_{2}$ & $27.0, \mathrm{CH}_{2}$ \\
\hline 12 & $32.5, \mathrm{CH}_{2}$ & $32.7, \mathrm{CH}_{2}$ & $32.5, \mathrm{CH}_{2}$ & $32.9, \mathrm{CH}_{2}$ \\
\hline 13 & $47.2, \mathrm{qC}^{2}$ & $47.0, \mathrm{qC}$ & $44.9, \mathrm{qC}$ & $45.1, \mathrm{qC}$ \\
\hline 14 & $47.5, \mathrm{qC}$ & $47.7, \mathrm{qC}$ & $47.9, \mathrm{qC}$ & $49.0, \mathrm{qC}$ \\
\hline 15 & $47.9, \mathrm{CH}_{2}$ & $46.1, \mathrm{CH}_{2}$ & $35.3, \mathrm{CH}_{2}$ & $35.6, \mathrm{CH}_{2}$ \\
\hline 16 & $77.5, \mathrm{CH}$ & $76.5, \mathrm{CH}$ & $29.3, \mathrm{CH}_{2}$ & $28.0, \mathrm{CH}_{2}$ \\
\hline 17 & $61.2, \mathrm{CH}$ & $59.3, \mathrm{CH}$ & $51.9, \mathrm{CH}$ & $52.0, \mathrm{CH}$ \\
\hline 18 & 19.1, $\mathrm{CH}_{3}$ & $19.8, \mathrm{CH}_{3}$ & $18.0, \mathrm{CH}_{3}$ & $18.1, \mathrm{CH}_{3}$ \\
\hline 19 & $29.9, \mathrm{CH}_{2}$ & $29.9, \mathrm{CH}_{2}$ & $32.1, \mathrm{CH}_{2}$ & $29.7, \mathrm{CH}_{2}$ \\
\hline 20 & $32.0, \mathrm{CH}$ & $36.4, \mathrm{CH}$ & $35.8, \mathrm{CH}$ & $36.4, \mathrm{CH}$ \\
\hline 21 & $19.9, \mathrm{CH}_{3}$ & $12.7, \mathrm{CH}_{3}$ & 17.6, $\mathrm{CH}_{3}$ & $18.3, \mathrm{CH}_{3}$ \\
\hline 22 & $50.4, \mathrm{CH}_{2}$ & 78.7, $\mathrm{CH}$ & $34.2, \mathrm{CH}_{2}$ & $39.0, \mathrm{CH}_{2}$ \\
\hline 23 & $202.6, \mathrm{qC}$ & $200.2, \mathrm{qC}$ & $154.8, \mathrm{qC}$ & 125.7, $\mathrm{CH}$ \\
\hline 24 & $125.1, \mathrm{CH}$ & $118.8, \mathrm{CH}$ & $108.4, \mathrm{CH}$ & $139.3, \mathrm{CH}$ \\
\hline 25 & 155.7, qC & $160.2, \mathrm{qC}$ & 119.7, qC & $70.9, \mathrm{qC}$ \\
\hline 26 & $20.8, \mathrm{CH}_{3}$ & $21.5, \mathrm{CH}_{3}$ & $136.9, \mathrm{CH}$ & $29.9, \mathrm{CH}_{3}$ \\
\hline 27 & $27.8, \mathrm{CH}_{3}$ & $28.2, \mathrm{CH}_{3}$ & $8.4, \mathrm{CH}_{3}$ & $29.8, \mathrm{CH}_{3}$ \\
\hline 28 & $22.2, \mathrm{CH}_{3}$ & $22.2, \mathrm{CH}_{3}$ & $113.6, \mathrm{CH}_{2}$ & $111.6, \mathrm{CH}_{2}$ \\
\hline 29 & $20.8, \mathrm{CH}_{3}$ & $21.4, \mathrm{CH}_{3}$ & $63.5, \mathrm{CH}_{2}$ & $19.7, \mathrm{CH}_{3}$ \\
\hline 30 & $20.1, \mathrm{CH}_{3}$ & $20.0, \mathrm{CH}_{3}$ & $18.8, \mathrm{CH}_{3}$ & $19.3, \mathrm{CH}_{3}$ \\
\hline
\end{tabular}

a) Recorded in $\mathrm{CDCl}_{3}$. b) Recorded in acetone- $d_{6}$.

3 and CHAGO cell lines with $\mathrm{IC}_{50}$ values of $5.58,7.24$ and $5.51 \mu \mathrm{M}$, respectively, while compounds $\mathbf{2}-\mathbf{8}$ displayed any detectable cytotoxicity against any of the five cell lines tested at the initial screening dose of $1 \mathrm{mg} / \mathrm{ml}$.

\section{Experimental}

General Experimental Procedures Optical rotations were measured on a Perkin-Elmer 341 polarimeter at a wavelength of $589 \mathrm{~nm}$. UV data were recorded on Shimadzu UV-160 spectrophotometer. IR spectra were recorded on Bruker vector 22 Fourier transform infrared spectrophotometer. The NMR spectra were recorded on a Varian YH400 spectrometer at $400 \mathrm{MHz}$ for ${ }^{1} \mathrm{H}-\mathrm{NMR}$ and at $100 \mathrm{MHz}$ for ${ }^{13} \mathrm{C}$-NMR using tetramethylsilane (TMS) as the internal standard. HR-ESI-MS were obtained using a Bruker micrOTOF mass spectrometer.

Plant Material The fresh apical buds of G. obtusifolia were collected from Khonkaen Province, Thailand, in December 2009. A voucher specimen (BKF 162605) has been deposited at the Forest Herbarium, Royal Forest Department, Bangkok, Thailand.

Extraction and Isolation The fresh apical buds ( $400 \mathrm{~g})$ of G. obtusifolia were extracted with $\mathrm{MeOH}(21 \times 2$, each $3 \mathrm{~d})$. After removing the solvent in vacuo, the combined $\mathrm{MeOH}$ crude extract was suspended in $\mathrm{H}_{2} \mathrm{O}$ $(300 \mathrm{ml})$, then partitioned with EtOAc $(300 \mathrm{ml} \times 3)$, to afford EtOAc crude extract $(80 \mathrm{~g})$. The extract was fractionated by silica gel flash $\mathrm{CC}$, eluted with a gradient system of hexane-EtOAc and EtOAc- $\mathrm{MeOH}$ to yield 13 fractions (I-XIII). Fraction V was subjected to silica gel CC and eluted with a gradient system of acetone-hexane (from $1: 9$ to $1: 4$ ) to afford 8 $(53.9 \mathrm{mg}), \mathbf{1}(17.4 \mathrm{mg}), \mathbf{2}(37.8 \mathrm{mg})$ and $\mathbf{4}(10.5 \mathrm{mg})$. Fraction VI was separated on a silica gel column using acetone-hexane mixtures (from 1:9 to $3: 7)$ to give secaubryenol $(9,22.6 \mathrm{mg})$. Fraction IX was separated into 14 fractions (IXa-IXn) by CC over silica gel eluted with the mixtures of acetone-hexane (from $1: 4$ to $1: 1$ ), and it was found that subfractions IXh and IXn provided the pure compounds $7(10 \mathrm{mg})$ and $\mathbf{6}(55 \mathrm{mg})$, respectively. Subfraction IXk was further purified by silica gel $\mathrm{CC}$, eluted with 1:99 $\mathrm{MeOH}-\mathrm{CH}_{2} \mathrm{Cl}_{2}$, to yield $3(70 \mathrm{mg})$. Fraction XI was then applied to a silica gel column and eluted with $\mathrm{MeOH}-\mathrm{CH}_{2} \mathrm{Cl}_{2}$ (from $3: 97$ to $8: 92$ ) to afford 5 (748.5 mg).
Gardenoin E (1): White, amorphous solid; $[\alpha]_{\mathrm{D}}^{25}-19.0(c=0.1, \mathrm{MeOH})$; $\mathrm{UV}(\mathrm{MeOH}) \lambda_{\max }(\log \varepsilon) 305.1$ (3.18); IR (KBr) 3439, 2939, 1712, 1617, $1443,1378,1117,1035 \mathrm{~cm}^{-1}$; ${ }^{1} \mathrm{H}$ - and ${ }^{13} \mathrm{C}$-NMR data, see Table 1; HR-ESIMS $m / z$ 477.3341 [M+Na] ${ }^{+}$(Calcd for $\mathrm{C}_{30} \mathrm{H}_{46} \mathrm{O}_{3} \mathrm{Na}, 477.3345$ ).

Gardenoin F (2): White, amorphous solid; $[\alpha]_{\mathrm{D}}^{25}-21.0(c=0.1, \mathrm{MeOH})$; $\mathrm{UV}(\mathrm{MeOH}) \lambda_{\max }(\log \varepsilon) 433.9$ (2.56), 238 (3.90); IR (KBr) 3443, 2935, 1704, 1614, 1452, 1398, 1108, $1063 \mathrm{~cm}^{-1} ;{ }^{1} \mathrm{H}$ - and ${ }^{13} \mathrm{C}-\mathrm{NMR}$ data, see Table 1; HR-ESI-MS $m / z$ 493.3289 [M+Na] ${ }^{+}$(Calcd for $\mathrm{C}_{30} \mathrm{H}_{46} \mathrm{O}_{4} \mathrm{Na}, 493.3294$ ).

Gardenoin G (3): White, amorphous solid; $[\alpha]_{\mathrm{D}}^{25}+45.0(c=0.1, \mathrm{MeOH})$; UV (MeOH) $\lambda_{\max }(\log \varepsilon) 275.1$ (3.01); IR (KBr) 3426, 2939, 1708, 1456, $1378,1045,1026 \mathrm{~cm}^{-1} ;{ }^{1} \mathrm{H}$ - and ${ }^{13} \mathrm{C}$-NMR data, see Table 1; HR-ESI-MS $m / z 507.3087[\mathrm{M}+\mathrm{Na}]^{+}$(Calcd for $\mathrm{C}_{30} \mathrm{H}_{44} \mathrm{O}_{5} \mathrm{Na}, 507.3086$ ).

Gardenoin H (4): Colorless gum; $[\alpha]_{\mathrm{D}}^{25}+22.0(c=0.1, \mathrm{MeOH})$; UV $(\mathrm{MeOH}) \lambda_{\max }(\log \varepsilon) 232.0$ (3.17); IR (KBr) 3426, 2921, 1708, 1460, 1372, $1273,1155 \mathrm{~cm}^{-1}$; ${ }^{1} \mathrm{H}$ - and ${ }^{13} \mathrm{C}-\mathrm{NMR}$ data, see Table 1 ; HR-ESI-MS $\mathrm{m} / \mathrm{z}$ $479.3496[\mathrm{M}+\mathrm{Na}]^{+}\left(\mathrm{Calcd}\right.$ for $\left.\mathrm{C}_{30} \mathrm{H}_{48} \mathrm{O}_{3} \mathrm{Na} 479.3501\right)$.

Cytotoxicity Assay Cytotoxicity was evaluated against five human tumor cell lines using 3-(4,5-dimethylthiazol-2-yl)-2,5-diphenyltetrazolium bromide (MTT) colorimetric method as previously reported. ${ }^{11,12)}$ The following tumor cell lines were used in the assay; human breast ductal carcinoma ATCC No. HTB 20 (BT474), undifferentiated lung carcinoma (CHAGO), liver hepatoblastoma (Hep-G2), gastric carcinoma ATCC No. HTB 103 (KATO-3), and colon adenocarcinoma ATCC No. CCL 227 (SW-620). All cell lines were obtained from the Institute of Biotechnology and Genetic Engineering, Chulalongkorn University, and were cultured in RPMI-1640 supplemented with $25 \mathrm{~mm} N$-(2-hydroxyethyl)piperazine- $N^{\prime}$-2-ethanesulfonic acid (HEPES), $0.25 \%(\mathrm{w} / \mathrm{v})$ sodium bicarbonate, $5 \%(\mathrm{v} / \mathrm{v})$ fetal bovine serum, and $100 \mu \mathrm{g} / \mathrm{ml}$ kayamycin.

Acknowledgment Financial support from the Thailand Research Fund (Grant no. DBG5380038) and the 90th Anniversary of Chulalongkorn University Fund (Ratchadaphisek Somphot Endowment Fund) is gratefully acknowledged. We are also grateful for the research fund from the Thai Government Stimulus Package 2 (TKK25555), under the Project for Establishment of a Comprehensive Center for Innovative Food, Health Products and Agriculture.

\section{References}

1) Silva G. L., Gil R. R., Cui B., Chai H., Santisuk T., Srisook E., Reutrakul V., Tuchinda P., Sophasan S., Sujarit S., Upatham S., Lynn S. M., Farthing J. E., Yang S.-L., Lewis J. A., O’Neill M. J., Farnsworth N. R., Cordell G. A., Pezzuto J. M., Kinghorn A. D., Tetrahedron, 53, 529-538 (1999).

2) Tuchinda P., Pompimon W., Reutrakul V., Pohmakotr M., Yoosook C., Kongyai N., Sophasan S., Sujarit S., Upathum S., Santituk T., Tetrahedron, 58, 8073-8086 (2002).

3) Reutrakul V., Krachangchaeng C., Tuchinda P., Pohmakotr M., Jaipetch T., Yoosook C., Kasisit J., Sophasan S., Sujarit K., Santisuk T., Tetrahedron, 60, 1517-1523 (2004).

4) Tuchinda P., Saiai A., Pohmakotr M., Yoosook C., Kasisit J., Napaswat C., Santisuk T., Reutrakul V., Planta Med., 70, 366-370 (2004).

5) Grougnet R., Magiatis P., Mitaku S., Loizou S., Moutsatsou P., Terzis A., Cabalion F. T., Miche S., J. Nat. Prod., 69, 1711-1714 (2006).

6) Lu R. F., Aeng Y. R., Wang W. C., Sheng Chih Yu Bi Yun, 12, 16-18 (1981).

7) Takase H., Imanishi K., Miura O., Yumioka E., Watanabe H., Jpn. J. Pharmacol., 49, 301-308 (1989).

8) Laurens A., Mboup S., Tignokpa M., Sylla O., Masquelier J., Pharmazie, 40, 482-484 (1985).

9) Hussian M. M., Sokomba E. N., Shok M., Int. J. Pharmacogn., 29, 94-100 (1991).

10) Manson D. J., Malaria Inst. India, 2, 85-93 (1939).

11) Nuanyai T., Sappapan R., Teerawatananond T., Muangsin N., Pudhom K., J. Nat. Prod., 72, 1161-1164 (2009).

12) Nuanyai T., Chokpaiboon S., Vilaivan T., Pudhom K., J. Nat. Prod., 73, $51-54$ (2010).

13) Sun H., Qiu S., Lin L., Wan Z., Lin Z., Pengsuparp T., Pezzuto J. M., Fong H. H. S., Cordell G. A., Farnsworth N. R., J. Nat. Prod., 59, $525-527$ (1996).

14) Cantillo-Ciau Z., Brito-Leoza W., Quijino L., J. Nat. Prod., 64, 953955 (2001).

15) Chen Y., Lin Z., Zhang H., Sun H., Phytochemistry, 29, 3358-3359 (1990).

16) Tan R., Xue H., Li L.-N., Planta Med., 57, 87-88 (1991).

17) Kunert O., Sreekanth G., Babu G. S., Adavi Rao B. V. R., Radhakishan M., Kumar B. V., Saf R., Narasimha Appa Rao A. V., Schuhly W., Chem. Biodivers., 6, 1185-1192 (2009). 